\title{
STRATEGI PARIWISATA EKOLOGIS DALAM TANTANGAN MASA PANDEMIK COVID-19
}

\author{
Gita Paramita Djausal ${ }^{* 1}$, Alia Larasati², Lilih Muflihah \\ 1Jurusan Ilmu Administrasi Bisnis, FISIP, Universitas Lampung \\ 2Yayasan Sahabat Alam, Lampung \\ 3Jurusan Ilmu Pemerintahan, FISIP, Universitas Lampung \\ *gita.djausal@fisip.unila.ac.id
}

\begin{abstract}
ABSTRAK
Sektor pariwisata terkena dampak di masa pandemik covid-19. Hal ini disebabkan oleh minimnya mobilitas masyarakat untuk menghindari penyebaran virus. Pengelolaan destinasi pariwisata ekologis patut mendukung pelestarian lingkungan dan secara bersamaan memberikan pengalaman kepada wisatawan. Terdapat dua isu utama pada masa pandemik; isu kesehatan dan keterbatasan mobilitas wisatawan. Hal tersebut yang mendorong munculnya dua isu strategis yang menjadi pertimbangan; strategi adaptasi internal (pengembangan produk turunan hasil konservasi) dan strategi wisata daring (perancangan wisata daring).
\end{abstract}

Kata kunci: ekowisata, pariwisata ekologis, strategi pengembangan pariwisata

\begin{abstract}
Tourism is affected by the covid-19 pandemic. It is caused by the limitation of people mobility in order to reduce the spread of the virus. Ecological tourism destinations management should support the environmental preservation and also give experience to the tourists. There are two main issues on this pandemic; health issue and limitation of tourist's mobility. This condition, bring up two strategic issues for consideration; strategy on internal adaptation (improvement on derivative products of nature resources) and strategy on online tourism (designing online tourism).
\end{abstract}

Keywords: ecotourism, ecological tourism, strategic tourism development

\section{PENDAHULUAN}

Sejak Desember 2019, dunia dihadapkan kepada isu kesehatan yaitu tersebarnya wabah covid-19. Wabah ini diduga penyebaran pertama di Wuhan, Tiongkok. Organisasi 
internasional, World Health Organization (WHO) menyatakan kondisi ini sebagai pandemik global pada 11 Maret 2020. Kampanye pentingnya mencegah penyebaran virus menjadi krusial. Penggunaan masker, mencuci tangan, dan menjaga jarak (pembatasan fisik) adalah protokol kesehatan yang harus dijalankan.

Sebagian daerah di Indonesia menerapkan kebijakan pembatasan sosial berskala besar (PSBB) untuk menekan penyebaran virus tersebut. Operasional kantor (pemerintah dan swasta) menerapkan kerja di rumah (work from home). Sekolah dan perguruan tinggi melaksanakan aktivitas belajar dengan sekolah di rumah (school from home).

Namun demikian berdampak pada aktivitas masyarakat. Mobilitas orang menjadi terbatas, dan bahkan terhenti. Aktivitas dilakukan di ruang privat (rumah). Lebih jauh, hal ini juga berdampak pada aktivitas ekonomi. Pemenuhan kebutuhan tertuju utama pada kebutuhan primer dan sekunder, bukan pada kebutuhan tersier.

Berdasarkan informasi Dcode Economic \& Financial Consulting (2020), melalui infografis yang mengilustrasikan kondisi ekonomi di Mesir, sektor pariwisata adalah sektor terdampak terburuk akibat pandemik global ini. Bertolak belakang dengan industri kesehatan yang memiliki potensi pemenang dalam kondisi ini.

\section{PEMBAHASAN}

\section{Masa Pandemik Covid-19 dan Mobilitas Manusia}

Dunia internasional dihadapi kondisi penyebaran dengan peningkatan jumlah pasien terkonfirmasi positif. Kebijakan lockdown dan PSBB mempengaruhi arus pergerakan barang dan manusia. Sektor bisnis yang bergantung pada arus antar negara dan juga antar provinsi/daerah menghadapi tantangan terbesar.

Industri transportasi, khususnya yang memberikan pelayanan antar kota/provinsi dilakukan pembatasan hingga dihentikan sementara. Pada Maret 2020, PT. Kereta Api Indonesia secara bertahap melakukan penutupan jalur antar provinsi, dan juga memberlakukan kebijakan pengembalian pemesanan tiket sebesar 100 persen. Pemerintah juga mengeluarkan kebijakan untuk pelarangan pesawat komersil mengangkut penumpang selama 24 April sampai dengan 1 Juni 2020. Bahkan penyebrangan laut (Bakauheni-Merak) ditutup sementara pada 24-27 April 2020, Pelabuhan Merak melakukan pembatasan layanan sampai dengan 31 Mei 2020.

Hal ini berdampak terhadap destinasi wisata. Perkembangan teknologi transportasi memiliki peranan terhadap arus wisatawan yang datang di tempat tujuan wisata. Transportasi adalah satu dari tujuh faktor pendukung jalannya pariwisata (Tambunan, 2009), berkaitan dengan ketersediaan dan kualitas perjalanan. Kondisi pandemik covid-19 ini, dalam aspek ketersediaan menyebabkan masyarakat tidak dapat mengakses transportasi.

Masyarakat diminta untuk tetap diam di rumah, tidak melakukan perjalanan. Dalam buku Consumer Behavior in Travel and Tourism (1999), menyampaikan pandangan dan perdebatan mengenai pemenuhan kebutuhan pariwisata bagi manusia (konsumen). Hierarki kebutuhan Maslow memberikan penyederhanaan dalam pemahaman kebutuhan manusia, dalam hal ini, pariwisata dalam digolongkan sebagai pemenuh kebutuhan akan pengakuan. 


\section{Pariwisata Ekologis}

Mispersepsi dan kesalahpahaman dalam istilah ekowisata terjadi di masyarakat. Libosada Jr. (2009) menjelaskan perbedaan tersebut berdasarkan konsep dan aktivitas. Wisata alam menggunakan alam sebagai daya tarik, merupakan produk yang ditawarkan pariwisata secara umumnya, dan itu berbeda dengan ekowisata. Ekowisata dibuktikan atas dukungannya terhadap isu (lingkungan), kesadaran, dan eco-friendly.

Dalam pariwisata yang berhubungan dengan kekayaan alam/sumber daya alam, memberikan ruang interaksi antara manusia dan alam. Permasalahan mendasar hal ini adalah hubungan antara kekayaan alam dan manusia begitu erat hal ini menciptakan koneksi yang tidak terbantahkan, alam menawarkan bahan dasar pembuatan obat, makanan, bahkan perhiasan, hal inilah yang memotivasi untuk mengambil langsung dari alam secara berlebihan (Peres, 2016). Jika kegiatan pariwisata dapat memberikan dampak buruk bagi lingkungan, hal tersebut terjadi di Pantai Boracay, Filipina tahun 2018 dikarenakan sampah yang mencemari pantai tersebut. Ekowisata patutnya memberikan keseimbangan antara pemenuhan kebutuhan manusia berwisata dan juga dukungan terhadap pelestarian lingkungan.

Menurut Ordóñez dan Duinker (2010) pembangunan berkelanjutan adalah pertama sebuah kapasitas dalam memelihara stabilitas ekologi, sosial dan ekonomi dalam transformasi jasa biosfir kepada manusia, kedua memenuhi dan optimasi kebutuhan pada saat ini dan generasi mendatang, ketiga kegigihan atas sistem yang diperlukan dan dikehendaki (sosio-politik atau alam) dalam waktu tak terbatas, keempat integrasi dari aspek etika, ekonomi, sosial dan lingkungan secara koheren sehingga generasi manusia dan makkhluk hidup lain dapat hidup pada saat ini maupun pada masa mendatang tanpa batas, kelima memenuhi kebutuhan dan aspirasi dibawah faktor pembatas lingkungan, sosial dan teknologi, keenam hidup secara harmoni dengan alam dan yang lainnya dan ketujuh menjaga kualitas hubungan antara manusia dan alam.

Wisatawan dalam beraktivitas wisata, akan mendapatkan pengalaman. Pengalaman tersebut yang kemudian memberikan timbal balik kepada wisatawan. Terdapat enam (6) aspek yang sepatutnya dijalankan oleh ekowisata ${ }^{1}$ (Fennel, 2015, p. 14); (1) berbasis alam, (2) pelestarian, (3) pendidikan, (4) berkelanjutan, (5) distribusi manfaat, dan (6) etika/tanggung jawab. Pada aspek pendidikan, memungkinkan adanya transfer pengetahuan (transfer of knowledge) antara pengelola dan wisatawan.

\section{Pengembangan Strategi Pariwisata}

Dalam pengembangan strategi pengelolaan destinasi pariwisata ekologis memiliki dua kondisi yang harus dipertimbangkan, yaitu kondisi internal dan juga eksternal. Kondisi internal menyatakan mengenai pengelola mengatur sumber daya yang ada; sumber daya manusia dan sumber daya alam. Kondisi eksternal merujuk kepada interaksi dengan pihak terkait di luar organisasi atau perusahaan pengelola destinasi. Pihak terkait adalah pengunjung, masyarakat, pemerintah, swasta, dan juga pengunjung.

Kondisi eksternal, interaksi dengan pemerintah dan swasta program yang dilakukan adalah pendampingan dan juga kerja sama. Namun dengan menurunnya aktivitas ekonomi, pertumbuhan ekonomi pada kuartal I hanya mencapai 2,97\% (Bank Indonesia,

\footnotetext{
${ }^{1}$ Istilah ecotourism dalam Bahasa Indonesia memiliki dua istilah; ekowisata dan ekoturisme. Dalam penelitian ini, peneliti menggunakan istilah ekowisata.
} 
2020). Kondisi pandemi ini juga merubah kebijakan utama pemerintah mengacu pada kebutuhan pada aspek kesehatan.

Destinasi pariwisata ekologis memiliki pasar minat khusus (niche market). Hal ini dikarenakan dukungan aktivitas pariwisata terhadap kelestarian lingkungan. Destinasi wisata mendapat dampak sampah (waste) dari aktivitas wisata, pengelolaan sampah solid yang buruk menyebabkan tampilan estetika yang buruk sebagai akibat keadaan tempat pembuangan (Kaseva \& Moirana, 2010, p. 696). Pentingnya menekankan aspek pelestarian dan juga aspek etika/tanggung jawab manusia pada keberlanjutan alam.

Taman Kupu-Kupu Gita Persada (TKGP) adalah destinasi ekowisata yang berada di Bandar Lampung, Lampung. Daya tarik utama TKGP adalah kupu-kupu. Dalam pembentukan pengalaman wisatawan yang datang, pengelola mengaitkan hal tersebut dengan dukungan terhadap pelestarian kupu-kupu Sumatera.

Sebagian pengunjung TKGP berstatus siswa sekolah yang datang dengan sepengetahuan dan pendampingan pihak sekolah. Hal ini dikarenakan TKGP dapat digunakan sebagai laboratorium alam. Terjadinya transfer pengetahuan mengenai kaitan kehidupan kupu-kupu dan topik bahasan pelajaran merupakan pengalaman wisatawan yang menegaskan aspek pendidikan dan aspek distribusi manfaat.

Penutupan akses transportasi umum dan pembatasan transportasi pribadi dan kebijakan Kementerian Pendidikan dan Kebudayaan Republik Indonesia untuk belajar dari rumah mempengaruhi angka kunjungan TKGP. Pencegahan penyebaran virus corona-19, salah satunya dengan menghindari kerumuman. Destinasi wisata sebelum masa pandemik, merupakan titik kerumunan, dan saat ini, hal tersebut harus dihindari. Kondisi eksternal ini yang kemudian harus ditanggapi dengan strategi adaptasi kondisi internal.

Kondisi internal ini dapat merujuk sumber daya alam yang ada dan juga kegiatan operasional. Pengembangan strategi adaptasi pada aktivitas internal berkaitan dengan isu utama ekowisata, yaitu pelestarian lingkungan. Peningkatan konsentrasi pada perawatan, pengayaan habitat bagi pelestarian kupu-kupu, dan diversifikasi produk turunan.

Operasional rutin, termasuk perawatan area taman (area konservasi), penangkaran ulat kupu-kupu harus terus dijalankan, oleh karena itu, TKGP tidak dapat menghentikan aktivitasnya. Ini yang terkait aspek pelestarian dalam ekowisata. Diversifikasi produk harus dikembangkan sesuai dengan potensi yang dimiliki. Tanaman yang ada, dapat menjadi, sebagai ilustrasi, produk bibit tanaman, daun untuk minuman herbal, atau minuman peningkat imunitas.

Kondisi eksternal memberikan peluang pengembangan interaksi secara daring (online). Perkembangan teknologi daring saat ini didukung oleh penggunaan aplikasi yang tepat merupakan peluang pengembangan strategis bagi destinasi pariwisata. Pariwisata ekologis memiliki peluang dengan pasar yang unik untuk menggunakan teknologi informasi. Tantangannya adalah bekerja sama dengan dengan pihak yang memiliki kemampuan dan keahlian dengan mengembangkan pengalaman wisata pengunjung tanpa harus berada di tempat wisata untuk menjalankan strategi wisata daring.

Strategi tersebut patut didukung dengan ketepatan perancangan informasi dan skenario pengalaman wisatawan daring. Kemungkinan pembuatan aplikasi wisata ini, merupakan upaya untuk tetap melaksanakan aktivitas wisata tanpa harus melakukan perjalanan dan juga terhindar dari kerumuman. Selain itu, tawaran wisata daring memungkinkan peluang perluasan pasar internasional. 
Di masa yang akan datang, isu kesehatan menjadi pertimbangan dalam pelaksanaan operasional di lokasi destinasi. Penyediaan tempat cuci tangan, papan informasi protokol kesehatan, penggunaan masker, dan pembatasan jumlah wisatawan pada satu waktu. Hal ini menjadi upaya mendukung pola hidup bersih sehat dan pencegahan penularan virus.

\section{PENUTUP}

Kondisi pandemik covid-19 memberikan kondisi ketidakpastian bagi industri pariwisata. Hal tersebut mempengaruhi pengunjung (konsumen) dan juga pengelola. Masyarakat diminta untuk tetap di rumah memberikan konsekuensi menurunnya mobilitas dan pemenuhan kebutuhan atas pariwisata menjadi rendah.

Ekowisata sebagai bentuk pariwisata berbasis pelestarian lingkungan, memiliki urgensi untuk tetap melakukan aktivitas operasional. Hal ini diperlukan untuk tetap mendukung pelestarian lingkungan yang harus dilakukan secara berkesinambungan (terus menerus).

Terdapat dua isu utama yang menjadi pertimbangan pengambilan keputusan strategis, isu kesehatan dan keterbatasan mobilitas wisatawan. Hal ini dapat dihadapi dengan melakukan strategi adaptasi internal dan strategi wisata daring. Harapan di masa datang, destinasi ekowisata tetap berjalan untuk pelestarian lingkungan dan pendistribusian manfaat (pengetahuan) bagi wisatawan, baik yang berkunjung langsung, ataupun yang secara daring.

\section{DAFTAR PUSTAKA}

Bank Indonesia. (2020, Mei 5). Siaran Pers . Retrieved from Bank Sentral Repubik Indonesia: https://www.bi.go.id/id/ruang-media/siaran-pers/Pages/sp_223620.aspx

Dcode Economic \& Financial Consulting. (2020). Infographic | Dcode Economic \& Financial Consulting. Retrieved Mei 7, 2020, from Dcode Economic \& Financial Consulting: https:/ / dcodeefc.com/infographics

Fennel, D. A. (2015). Ecotourism (Forth ed.). Oxon: Routledge.

Jr., C. M. (2009). Business or leisure? Economic development and resource protection-Concepts and practices in sustainable ecotourism. Ocean \& Coastal Management, 52, 390-394.

Kaseva, M., \& Moirana, J. (2010). Solid waste management on Mount Kilimanjaro. Waste Management $\mathcal{E}$ Research, 28(8), 695-704.

Ordóñez, C., \& Duinker, P. (2010). Interpreting Sustainability for Urban Forests. Sustainibility, 1510-1522. doi:10.3390/su2061510

Peres, J. D. (2016). Overexploitation. In J. Reynolds, Principles of Conservation Biology, 3rd Edition (p. 249). Sinauer.

Pizam, A., \& Mansfeld, Y. (Eds.). (1999). Consumer Behavior in Travel and Tourism. New York: The Howard Hospitality Presss.

Spanou, S., Tsegenidi, K., \& Georgiadis, T. (2012). Perception of Visitors' Environmental Impacts of Ecotourism: A case study in the Valley of Butterflies Protected area, Rhode Island, Greece. International Jurnal for Environmental Research, 245-258.

Tambunan, N. (2009, Januari-Juni). Posisi Transportasi dalam Pariwisata. Majalah Ilmiah Panorama Nusantara, Vi, 39-48. 